\title{
АНАЛІТИЧНА ІНФОРМАЦІЯ ЯК ЗАСІБ ПІДГОТОВКИ УПРАВЛІНСЬКИХ РІШЕНЬ ОРГАНАМИ МІСЦЕВОГО САМОВРЯДУВАННЯ
}

\author{
Демчина Л. I., \\ к. н. із сои. комун., доц., доцент кафедри документознавства та інформаційної діяльності, \\ Івано-Франківський національний технічний університет нафти і газу \\ Украӥна, м. Івано-Франківськ
}

DOI: https://doi.org/10.31435/rsglobal_wos/30042020/7044

\section{ARTICLE INFO}

Received: 21 February 2020

Accepted: 15 April 2020

Published: 30 April 2020

\section{KEYWORDS}

information activity, analytical information, analytical document, management decisions, local authorities. \begin{abstract}
The information activity is becoming necessary for a society, one of the most important and influential factors of stability of any state in the modern conditions. The presence of analytical information in information activities makes them a reliable basis for management decision making. The content of the concept of "analytical information" is clarified in the proposed research. The specifics of analytical documents functioning in the field of public administration are characterized. The determining principle for preparing such analytical documents is the need to provide compressed information for its use without additional reference to the processed source materials. The ways to improve the functioning of analytical information in the department of information activity and public communications of the regional administration are suggested.
\end{abstract}

Citation: Демчина Л. І. (2020) Analitychna Informatsiia yak Zasib Pidhotovky Upravlinskykh Rishen Orhanamy Mistsevoho Samovriaduvannia. International Academy Journal Web of Scholar. 4(46). doi: 10.31435/rsglobal_wos/30042020/7044

Copyright: (C) 2020 Демчина Л. I. This is an open-access article distributed under the terms of the Creative Commons Attribution License (CC BY). The use, distribution or reproduction in other forums is permitted, provided the original author(s) or licensor are credited and that the original publication in this journal is cited, in accordance with accepted academic practice. No use, distribution or reproduction is permitted which does not comply with these terms.

Вступ. У наш час людство наблизилось до створення глобальної інформаційної цивілізації, у якій інформація набуває значення найважливішого ресурсу. Особливістю поняття «інформація» $є$ його універсальність, тому що використовується практично у всіх сферах людської діяльності: природничих науках, філософії, біології, економіці, менеджменті тощо. Інформація відзначається смисловим навантаженням, дуже різноманітна, є фундаментальною основою та загальною властивістю Всесвіту, може бути об'єктом зберігання, передачі та перетворення. 3 цим поняттям та його поширеністю не може конкурувати будь-яке інше явище. Відомо, що інформація, а особливо аналітична - основа процесу управління. Без неї неможливо сформулювати проблему, вірно оцінити ситуацію, визначити цілі управління та прийняти рішення. Як вітчизняними так і зарубіжними дослідниками активно вивчаються окремі аспекти місця інформації та інтелектуальних ресурсів у процесі діяльності організації.

Необхідною умовою модернізації діяльності будь-якої організації в нашій країні $\epsilon$ впровадження сучасних інформаційно-комунікаційних технологій. Це неминуче тягне за собою переосмислення функцій та завдань усіх елементів організації, зміну іiі структури основних завдань та функцій. Інформація набуває статусу важливого капіталу, можна стверджувати, що такій тенденції повинні слідувати усі ієрархічні рівні управління державою. Для України, в якій на тлі економічних реформ питання формування інформаційної й аналітичної бази, основою якої $є$ саме аналітична інформація для прийняття управлінських рішень на державному рівні $\epsilon$ 
особливо актуальним. Технологія інформаційно-аналітичної діяльності передбачає одержання нового знання тобто аналітичної інформації.

Особливу роль інформації та інформаційних ресурсів в діяльності державних установ обумовлена їх безпосередньою участю у різних економічних процесах та постійним зростанням рівня інформатизації суспільства в цілому. Сучасний етап розвитку суспільства потребує використання науково-обгрунтованих методів збору, аналізу, обробки та застосування інформації і іiї взаємопов'язаних форм, що сприяє формуванню потенційних інформаційних ресурсів установи і послідовній реалізації напрямків ії розвитку [9].

Життєздатні системи управління повинні характеризуватись гнучкістю, мобільністю, здатністю адаптуватися й вчасно реагувати на зміни зовнішнього середовища, можливістю швидкої, комплексної перебудови на реалізацію нових завдань. Від цього значною мірою залежить стан державних установ, результатів їхнього функціонування, збереження й збільшення економічного потенціалу регіонів та країни. У такій ситуації роль основної підсистеми управління починає відігравати аналітична інформація у цій сфері діяльності. [11].

Певною мірою подолати невизначеність інформаційного середовища допомагають доступні знання та нагромаджені інформаційні масиви. Інформація, яка $є$ доступною, достатньо деталізованою та вчасною може значно покращити його прозорість [2].

Переосмислення побудови системи організації інфрмаційно-аналітичної діяльності, визначення ролі та місця аналітичної інформації у прийнятті управлінських рішень в системі державного управління. Однією із умов стабільного функціонування й ефективності реалізації напрямів діяльності державної установи $є$ використання аналітичної інформації, що й зумовлює актуальність дослідження.

Результати дослідження. Інформаційно-аналітична діяльність є важливою складовою праці управлінського персоналу; передумовою прийняття ефективних управлінських рішень. Це дозволяє зібрати дані в цілісну картину про те, що відбувається, й спрогнозувати на перспективу дії різних факторів, структур, груп інтересів. Інформаційно-аналітична робота забезпечує стадії визначення проблем системи управління та їх аналіз, а також підготовку управлінського рішення, контроль за його виконанням та оцінку його дієвості.

3'ясуємо значення ключових понять і термінів, що необхідні для розкриття теми дослідження, таких як «інформація», «аналітика», «аналітична інформація». Розпочнемо 3 головного поняття, на нашу думку - «інформація». Насамперед зазначимо, що однозначного трактування цього поняття на сьогодні не існує.

На думку Ю. П. Сурміна, «інформація - це нові відомості, що дозволять поліпшити процеси пов'язані з перетворенням речовини, енергії і самої інформації». Автор зазначає, що згідко з Р. А. Фатхутдімовим, інформація - це відомості, знання спостерігача про систему та середовище іiі функціонування, продукт інформування, що відображає або впливає на виділені властивості, особливості або показники досліджуваних явищ, об'єктів, організацій і знімає існуючу до його появи невизначеність. Проте, до того, як організація отримає необхідну інформацію, iї потрібно вибрати з безлічі даних, що знаходяться в інформаційному потоці. У цьому випадку дослідник схиляється до твердження, що дані це насамперед сирі факти до їх перетворення у форму, яку люди можуть розуміти та використовувати [13].

Дослідник К. В. Ілляшенко дотримується позиції, що інформація може розглядатися як: дані (відомості, факти), знання, міра невизначеності та ступень впорядкованості системи. Відповідно, автор подає тлумачення таким підходам, згідно із першим, інформація - це дані представлені у контексті. Тобто, підкреслюється ï зв'язок з даними, на базі яких вона отримана. Для перетворення даних на інформацію над ними проводяться наступні дії: контекстуалізація (угрупування даних за цілями); категоризація (виділення частин або ключових компонентів даних); калькуляція (статистичний аналіз даних); коректування (виведення помилкових відомостей $з$ даних); стискування (підсумовування даних в коротшій (стислій) формі). [4]. Такий підхід пояснює, що інформація може визначатися як знання, набуті шляхом власного дослідження. Тісний взаємозв'язок знань 3 людським чинником обумовлює їх певну суб'єктивність, оскільки одна і та ж інформація може бути по-різному інтерпретована. Інформація також може визначатися як усунення невизначеності стану системи.

В. А. Ребкало вважає, що у теорії управління доцільно застосовувати визначення інформації, як сукупність відомостей про зміни, що відбуваються у системі та іï 
навколишньому середовищі, що зменшує ступінь невизначеності знань про конкретний об'єкт, це обмін відомостями (даними) між людьми, користувачем i машиною, у середині автоматизованих систем. Інформація використовується як ресурс для виконання службових функцій, а також як засіб службових комунікацій, оскільки останні здійснюються в процесі передачі різних відомостей [10]. Інформація $є$ предметом, засобом і продуктом управлінської праці, цієї ж думки дотримується В. М. Варенко. Дійсно важливою є тільки та інформація, що зменшує невизначеність у конкретній управлінській ситуації [1, с. 57].

Поняття «аналітика» досліджували О. П. Дубас, О. М. Карпенко, Т. М. Стоколос. Дослідник О. М. Карпенко характеризує цей термін як цілісну сукупність принципів методологічного, організаційного та технологічного забезпечення індивідуальної та колективної розумової діяльності, що дозволяє ефективно опрацьовувати інформацію з метою вдосконалення якості наявних та оволодіння новими знаннями, а також підготовки інформаційної бази для прийняття оптимальних управлінських рішень [6].

На думку Т. М. Стоколос, під аналітикою розуміють, насамперед галузь діяльності, що стрімко розвивається і базується на одержані інформації за допомогою аналітичних методів для потреб практичної діяльності. Аналітику не можна ототожнювати з аналізом. Вона являє собою специфічне суспільне явище, а не тільки інструмент розумової діяльності людей [12].

Підтримуємо позицію дослідника О. П. Дубас, що саме аналітика [3]:

- забезпечує управлінців та бізнесменів необхідною і достатньою інформацією для прийняття своєчасного й ефективного управлінського рішення;

- діагностує, прогнозує, убезпечує управлінців від загроз та ризиків;

- допомагає уникнути кризових ситуацій в економіці та політиці, за допомогою отримання відповідної інформації;

- знижує інформаційне навантаження на осіб, що приймають управлінське рішення за рахунок фільтрації потоків інформації.

Що стосується аналітичної інформації, то вона являє собою відомості, отримані перевірених, співвіднесених фактів, які викладені таким чином, щоб відповідати вирішенню конкретного завдання. Аналітична інформація повинна відповідати наступним якісним характеристикам:

- цінність (корисність) - ступінь сприяння досягненню мети замовника інформації;

- точність - припустимий рівень викривлення інформації;

- достовірність - властивість інформації відображати реально існуючи об'єкти 3 необхідною точністю;

- повнота - необхідний обсяг відомостей для прийняття виваженого та ефективного рішення;

- оперативність - іншими словами, актуальність, відповідність інформації поточному моменту;

- коректність - однозначність сприйняття інформації всіма споживачами [14].

Дослідниця Н. Г. Калюжна переконана, що в організації використовують аналітичну інформацію в трьох основних цілях $[5$, с. 20]:

- для зниження ризику і зменшення невизначеності;

- для одержання влади і засобів впливу на інших;

- для контролю й оцінки продуктивності й ефективності організації.

За словами П. Ю. Конотопова, саме аналітична інформація є на сьогодні найціннішим продуктом на ринку інформації. Економічний глобалізм внаслідок закономірного технологічного стрибка перетворив інформаційну індустрію, що обслуговує процес економічного розвитку, в особливу, якісно нову галузь у загальній структурі економіки, що стала плацдармом, 3 якого, власне, почалася нова, інформаційна епоха. Розпочалося продукування товару нового типу, глобального товару з новими економічними властивостями, необмеженого відтворення й накопичення та багаторазового використання інформації, $\mathrm{i}$, що треба особливо підкреслити, якщо ми говоримо саме про аналітику, - масове створення нової інформації на основі первинної [7].

Протилежну думку стосовно аналітичної інформації висловлює дослідник А. С. Пересада та визначає іiі як сукупність знань, відомостей, що характеризують діяльність підприємства, організації, установи [8]. 
На сьогодні інформація набуває статусу важливого капіталу, можна стверджувати, що такій тенденції повинні слідувати усі ієрархічні рівні управління державою. Для України, в якій на тлі реформ питання формування інформаційної й аналітичної бази, основою якої є саме аналітична інформація для прийняття управлінських рішень на державному рівні $є$ особливо актуальним. Технологія інформаційно-аналітичної діяльності передбачає одержання нового знання тобто аналітичної інформації.

В органах місцевого самоврядування (далі - ОМС) аналітична інформація представлена у формі інформаційно-аналітичних документів. Аналітична інформація в ОМС утворюють у процесі здійснення:

- аналізу та прогнозу розвитку суспільно-політичних процесів у регіоні, підготовці інформаційно-аналітичних матеріалів та поданні відповідних пропозицій головам ОМС;

- аналізу діяльності політичних партій та громадських організацій, підготовці пропозицій щодо залучення зазначених організацій до вирішення соціально-економічних питань регіону;

- розробки оперативних інформаційно-пропагандистських матеріалів щодо суспільнополітичної ситуації в регіоні;

- здійсненні підготовки щоденної експрес-інформації для керівництва ОМС;

- аналізу, узагальнення та прогнозу розвитку ситуації в інформаційному просторі області;

- забезпеченні постійного моніторингу громадсько-політичних настроїв населення та оцінці суспільно-політичної ситуації в регіоні;

- аналізу розстановки основних політичних сил у регіоні та динаміку їх впливу на соціально-політичний процес;

- задля ефективності розробок матеріалів 3 політичного прогнозування залучення науковців, політологів, представників політичних партій, громадських організацій, незалежних експертів;

- забезпечення розробки аналітичних матеріалів щодо суспільно-політичної та соціально-економічної ситуації в регіоні;

- щоденного оперативного інформування Адміністрації Президента України, Кабінету Міністрів України, керівництва обласної державної адміністрації про стан та тенденції суспільно-політичних процесів та основні події соціально-економічного життя в регіоні;

- підготовки інформаційно-аналітичних матеріалів 3 питань суспільно-політичної ситуації для доповідей голові обласної державної адміністрації, а також матеріали з брифінгів, прес-конференцій, засідань за круглим столом, що проводяться в ОМС;

- висновків, пропозицій та зауважень, що надійшли під час проведення консультацій 3 громадськістю, сприянні врахуванню громадської думки під час прийняття рішень місцевими органами виконавчої влади;

- моніторингу проведення мирних зібрань, організовує в установленому порядку, разом з іншими структурними підрозділами ОМС, розгляду вимог учасників зазначених акцій та інформуванні про результати;

- моніторингу висвітлення засобами масової інформації діяльності ОМС, організації оперативного реагування на критичні публікації, виступи, повідомлення тощо;

- 3 відповідними структурними підрозділами облдержадміністрації проведення аналізу діяльності громадських організацій в області, підготовці пропозиції щодо заходів, спрямованих на поліпшення взаємодії обласної державної адміністрації з громадськими організаціями стосовно здійснення соціально-економічних реформ, розбудови демократії, соціальної, правової держави, розвитку громадянського суспільства;

- надання організаційно-методичної, експертно-аналітичної та іншої допомоги структурним підрозділам обласної державної адміністрації, райдержадміністраціям у вирішенні питань, що стосуються інформаційної діяльності та комунікацій з громадськістю;

- змістового наповнення веб-сайту облдержадміністрації в мережі Інтернет та подання інформаційно-аналітичних матеріалів у засоби масової інформації.

Інформаційну складову управлінської діяльності становить збирання, зберігання, опрацювання та передача аналітичної інформації. А ОМС уся робота із інформацією, для отримання аналітичної, складається 3 таких складових: збір неопрацьованих даних; переміщення інформації від одного джерела до іншого; опрацювання та перетворення 
інформації з однієї форми в іншу; зберігання опрацьованої інформації; пошук та доступ до інформації, що зберігається; формування інформації у вигляді, зручному для користувача.

Своєчасність аналітичної інформації залежить від природи прийнятих на іiі основі рішень. У ряді випадків немає необхідності одержувати інформацію миттєво, якщо ухвалення рішення потребує часу. Повнота та регулярність аналітичної інформації передбачає систематичне надходження та добре організоване збереження даних, які надходять. Регулярна i належним чином підтримувана в архівах інформація потрібна для реєстрації змін у показниках та аналізу тенденцій цих змін.

Підготовленість аналітичної інформації до застосування дозволяє ефективніше використовувати іiі для прийняття управлінських рішень і знижувати стресогенність керівної роботи. Створення якісної аналітичної інформації у департаменті відповідає критеріям надійності, своєчасності, повноти і регулярності, а також підготовленості до застосування.

В ОМС фахівці здійснюють підготовку аналітичної інформації у три етапи: щоденна підготовка інформації, щотижнева та щомісячна. Важливою умовою підготовки аналітичної інформації є іiі своєчасність та актуальність.

Зокрема, в департаменті інформаційної діяльності та комунікацій з громадськістю обласної державної адміністрації (далі - департамент) щоденна підготовка інформації передбачає моніторинг громадсько-політичних настроїв населення та оцінку суспільнополітичної ситуації в області на основі моніторингу електронних ЗМІ. Такий вид документа, потребує опрацювання масиву інформації, що висвітлена у місцевих Інтернет-виданнях про суспільно-політичну ситуацію для отримання аналітичної інформації і відповідно оформлення ii у вище зазначений інформаційно-аналітичний документ. Моніторинг здійснюють двічі на день (до 10.00 год. та до 15.00 год.) і надсилається електронною поштою директору департаменту та у приймальню голови обласної державної адміністрації. За аналогією проводиться щоденний моніторинг телебачення.

Створення інформаційно-аналітичних документів поєднує методику інформаційного аналізу і синтезу, тобто зосередження на основних положеннях, фактах, даних з відкиданням надлишкової інформації. Одержана аналітична інформація допомагає зорієнтуватися не лише в потоці первинних документів, а й у змісті проблеми в цілому. Особливу роль відіграють аналітичні документи в ухваленні виважених управлінських рішень, а також попередження резонансних ситуацій, масових мітингів та протестів, що можуть назрівати в області. Важливо з'ясувати не тільки суперечливу природу фактів, їх джерела, але й способи здобування, вивчення інформації з метою іiі осмислення та передачі відповідній аудиторії. Вміння шукати, опрацьовувати інформацію - частина діяльності спеціалістів департаменту, що з огляду на різні причини є особливо актуальною сьогодні.

Методи, які застосовуються для збору інформації у департаменті, насамперед, забезпечують ії якість. Надійність інформації на практиці досягається за рахунок методологічно правильної техніки іiі одержання, а також шляхом повторного огляду отриманих даних. Для здійснення моніторингів суспільно-політичної ситуації в області, діяльності облдержадміністрації та громадсько-політичних настроїв населення, а як результат створення аналітичної інформації, використовують такі інформаційні ресурси як інтернет-видання, друковані засоби масової інформації та телебачення.

Висновки. Усе зазначене вище дає змогу зробити висновок, що інформаційно-аналітична діяльність в ОМС безсумнівно $є$ широкою і багатогранною сферою діяльності. Вона включає в себе підбір та систематизацію фактів щодо певного питання, в основному це стосується суспільно-політичної ситуації у області, їх оцінку, відбір, тлумачення, чітке й продумане викладення в письмовій формі, у формі інформаційно-аналітичних документів. Названі документи виступають засобом інформаційної підтримки прийняття управлінських рішень, дозволяють економити час фахівців, позбавляють від необхідності безпосереднього перегляду документів під час пошуку потрібних матеріалів, акцентують увагу на найважливішій інформації. Аналітична інформація у департаменті створюється систематично, висвітлюючи суспільнополітичну ситуацію в області 3 використанням місцевих засобів масової інформації. Для забезпечення користувачів необхідною, систематизованою, опрацьованою та проаналізованою інформацією створюються аналітичні документи, вихідні джерела яких $є$ лише засобом виявлення та перетворення первинної інформації. Визначальним принципом підготовки таких 
аналітичних документів $є$ необхідність надання згорнутої інформації, для ії використання без додаткового звернення до опрацьованих вихідних матеріалів.

У процесі аналізу діяльності департаменту виявлено низку проблем, які потребують вирішення задля удосконалення організації аналітичних документів для процесу створення та прийняття управлінських рішень. Виявлені проблеми можна розділити на три групи: відсутність єдиної нормативно-методичної бази здійснення інформаційно-аналітичної діяльності; потреба у формуванні системи професійних кадрів спеціалістів-аналітиків, які займаються інформаційноаналітичною діяльністю; урізноманітнення та удосконалення змісту аналітичних документів.

\section{ЛIТЕРАТУРА}

1. Варенко В. М. Інформаційна аналітика в Україні: необхідність впровадження, проблеми функціонування, перспективи розвитку. Вісник ЛНУ. 2013. № 1. С. 18-23.

2. Гребешков О. М. Інформаційне забезпечення діяльності підприємства: інформаційні потреби та джерела їх задоволення. Вісник Хмельницького наиіонального університету. 2009. № 6. Т. 3. С. 205-208.

3. Дубас О. П. Інформаційний розвиток сучасної України у світовому контексті. К. , 2011. 276 с.

4. Ілляшенко К. В. Аналіз інформаційного забезпечення діяльності організації. Збірник наукових праць ТДАТУ (економічні науки). 2012. № 17. С. 187-193.

5. Калюжная Н. Г. Гносеологічний та системний аспект тлумачення поняття «інформація». Бізнес Інформ. 2011. № 10. С. 18-21.

6. Карпенко О. М. Понятійно-категоріальний апарат науки державного управління у сфері інформаційно-аналітичного забезпечення діяльності органів виконавчої влади. Вісн. Кн. палати. 2011. № 5. С. 3-13.

7. Конотопов П. Ю. Аналітика: методологія та технологія. К. 2011. 512 с.

8. Пересада А. С. Формування комунікаційного процесу в організації. Інформаційні технології. 2009. № 7. C. 7-15.

9. Пугач А. О. Сутність процесу інформаційно-аналітичного забезпечення органів державної виконавчої влади в Україні. Державне управління: удосконалення та розвиток. 2010. № 8, 2010. URL:http://www.dy.nayka.com.ua

10. Ребкало В. А. Аналітика та прогнозування: навч. посіб. К., 2011. 60 с.

11. Самойленко М. В., Пашенко Г. В. Вдосконалення інформаційного забезпечення діяльності підприємства TOB «KOHCTAHTA+». URL: http://www file:///C:/Users/user/Downloads/1248-2528-1-SM\%20(2).pdf

12. Стоколос Т. М. Інформатизація та інфораційне забезпечення: підходи до трактування понять. Науковий вісник НЛТУ. 2011. № 18. С. 296-301.

13. Сурмін Ю. П. Аналітика державного управління: сутність і тенденції розвитку. Інформаційний менеджмент. 2012. № 10. C. 20-27. URL: http://www.academy.gov.ua/

14. Телешун С. О. Інформаційно-аналітична діяльність в державному управлінні: навч.-метод. матеріали. К., 2013. 36 с. 